as Ap. Belopolsky's groups have been verified and added to, and the lines have been respectively identified with those of europium and terbium. Many of the lines not definitely recognised as being of variable intensity have further been found to agree with the stronger lines of yttrium, lanthanum, gadolinium, and dysprosium. The peculiarities of the spectrum thus appear to arise from the exceptional development of lines belonging to rare earths. It may be added that the presence of europium lines in this spectrum was first detected by Mr. Baxandall, of the Solar Physics Observatory, Cambridge.

The Society for Practical Astronomy.-The annual report of the president of this society for 1916-I7 is included in the Monthly Register, vol. ix., No. 2 (I338 Madison Park, Chicago, Ill.). The chief purpose of the society is to promote the practical study of astronomical phenomena, and to encourage co-operation among its members through the various observing sections which have been organised. A section for the teaching of astronomy, under the direction of Dr. Mary E. Bird, appears to have been especially successful. There is also a section for the construction of astronomical instruments, which is directed by Prof. M. F. Fullan, who is contributing a valuable series of articles on the construction of a Newtonian reflector, from the grinding and figuring of the mirror to the actual mounting of the telescope.

\section{BUTTER SUBSTITUTES.}

$\mathrm{T}$ HE present shortage of fats, especially butter, gives a particular interest to two papers published by the Society of Chemical Industry. The first, printed in the Journal for October $3 \mathrm{I}$ last, is by Dr. A. Lauder and Mr. T. W. Fagan, who experimented on the utilisation of fatty acids for feeding purposes. The large increase in glycerol manufacture for explosives has resulted in the production of a quantity of fatty acids much in excess of what can ordinarily be utilised. According to the view now held of the digestion of fat in the animal organism, there does not seem to be any physiological reason why it should not assimilate free fatty acids. In the authors' experiments ten young pigs (about seven weeks old) were fed, the first five on a mixture of maize meal and sharps, the remaining five on a smaller ration of the meal and sharps mixture, together with a small quantity of the fatty acids from coconut oil. About $5 \mathrm{oz}$. of the fatty acids replaced $\mathrm{I} \mathrm{lb}$. of the meals. In addition to the above rations, a certain quantity of cabbage was given to the pigs. The results showed that the increases in the live weights of the two lots of pigs when the experiment had lasted for seven weeks were practically identical. The conclusion is drawn that the fatty acids were assimilated, and that they replaced about two and a half times their weight of carbohydrate.

The second paper, published in the issue of December ${ }_{15}$, by Mr. W. Clayton, deals with "Modern Margarine Technology." The first butter substitute was prepared at the time of the Franco-Prussian War by Mège-Mouriès, who digested animal fat with sodium carbonate solution in the presence of pepsin (from pig or sheep stomach), the product being afterwards churned with ro per cent. of cow's milk and water containing macerated cow's udder. In modern margarine manufacture the fat is no longer artificially digested with pepsin, whilst animal fat is more and more being replaced by vegetable oils (coconut, palmkernel, cotton-seed, arachis, soja-bean, sesame, kapok. maize, and wheat), and by hardened or hydrogenated oil. It has been established that the very small quantity of nickel which remains in the hydrogenated oil NO. 2516 , VOL. IOO] is quite harmless. In the preparation of margarine milk is used for two primary reasons : first for flavouring purposes, and secondly as an emulsifying agent. The milk is pasteurised by heating at $82^{\circ} \mathrm{C}$. for a few minutes (a possible improvement would be to sterilise it by means of ultra-violet light or a high-tension alternating current), cooled to $I 0^{\circ} \mathrm{C}$., and delivered into souring tanks. In the latter it is inoculated with lactic acid bacilli and the temperature then raised to the point favourable to lactic fermentation. When the fermentation has proceeded so far that the acidity causes a rapid precipitation of curd the milk is again cooled to a safe inhibiting temperature. The mixture of vegetable and animal fats and oils is melted strained, and brought to a suitable temperature (best $25^{\circ} \mathrm{C} .-35^{\circ} \mathrm{C}$.). It is then run into a churn containing the prepared milk (the milk is sometimes added to the oil, but then emulsification is not so good), and the mixture emulsified by the action of revolving baffieplates. The emulsion is allowed to flow on to a slanting shoot, where it meets a spray of ice-cold water. This causes immediate solidification and a breaking up of the mass into yellow granules. These granules, after draining, are kept at a constant temperature in a maturing room, where the bacteria introduced by the milk can develop. Maturing takes longest in the case of the best animal margarines. When mature the product is kneaded to form a coherent butter-like mass and to expel the excess of moisture, and then passes to the blending department, where it is prepared for sale. Boric acid (not exceeding 0.5 per cent.) is generally added as a preservative. Lactic fermentation imparts to the milk a pleasant acid taste, but does not give it the true butter flavour. Much research will be necessary before margarine can be made with a taste like that of butter.

E. H.

\section{SEA-PENS OF THE "SIBOGA" EXPEDITION.}

THE Pennatulacea of the Siboga expedition-the richest collection of sea-pens made by a single expedition-comprise about $55^{\circ}$ specimens, which Prof. Hickson has referred to seventeen genera and forty-five species (seventeen new). Having at his disposal this, wealth of material, and other specimens in his own collection and in that of the University of Manchester, Prof. Hickson has taken the opportunity of making a thorough survey and revision of the order. He regards the order as consisting of only a few well-marked generic groups, and considers that new generic names should not be introduced without very strong reason. No new generic name is proposed in this memoir, and several recently described genera have been merged in older ones. Prof. Hickson carefully defines the descriptive terms employed in his memoir in the hope that henceforward there may be a greater measure of uniformity in the terminology; certainly he has set a high staridard of precision in the systematic descriptions.

In the course of interesting speculations on the hypothetical ancestor and the evolution of sea-pens, Prof. Hickson says he is inclined to believe that Cavernularia is nearer the ancestral form-which he suggests was a dimorphic Alcyonacean similar in build to Sarcophytum trochiforme-than Lituaria, which Prof. Kükenthal considered to be the most primitive sea-pen.

Pennatulacea were obtained by the expedition from sixty-five of the 322 collecting stations, and the names

1 "The Pennatulacea of the Sibnga Expedition, with a Gener.l Si rvey of the Order." By Prof. S. J. Hickson. Pp. $x+265$ tp'ates $x+r$ chart. (Leyden: E. J. Brill, Jgr6.) Price 13.50 franc:. 